\title{
Virtual Groups and the Development of Self- protection During the Coronavirus Pandemic (COVID-19)
}

Mohamed Mohamed Selem Ahmed (PhD)

Associate Professor, Group Work Department College of Social Work - Helwan University 



\section{Abstract}

This study focuses on the role of virtual groups and the development of self-protection during the Corona pandemic (COVID19). This study applies both descriptive and analytical approaches; it uses social survey as a method for collecting social data through electronic questionnaires. Moreover, it is applied on students who are members in virtual groups in the College of Arts and Social Science, Sultan Qaboos University, during the period from March 2021 until May 2021.

The results show a statistically significant correlation between the roles of virtual groups and the tools they use to develop self-protection during the Corona pandemic. Finally, the virtual groups roles are not enough to develop self-protection during the coronavirus pandemic (COVID-19).

Key words: Virtual groups - Covid-19 pandemic - Self-protection. Introduction:

The first outbreak of Covid-19 caused by the novel SARS-CoV-2 coronavirus was reported in December 2019 in Wuhan, China. The disease rapidly spread in 2020 and the ensuing global Covid-19 pandemic has resulted in large-scale loss of life, debilitating illness and major socioeconomic disruption. The disease has severely disrupted education at all levels and consequently the lives of students of all ages. Throughout the world, university students have been affected through campus closures, unplanned rapid shifts to online learning such as social distancing, mask wearing and travel restrictions to curb transmission of the virus (Ihm, Zhang, Vijfeijken, \& Waugh, 2021, pp. 1-2).

This has been corroborative with one of the articles by Sharma, Vashnav, \& Sharma (2020) which indicates that "the COVID-19 pandemic hype has caused huge loss to the world community, but substantial gains are also being witnessed. Media coverage should be balanced. Intensive public awareness programs coupled with best possible medical treatment to symptomatic cases are recommended". It is worth mentioning that"COVID-19 has now infected over 20 million people and claimed more than 600,000 lives around the world" (Marques, et al., 2020, p. 1).

Also, potential stressors related to the virus might be the fear of infection with COVID-19 and the perceived risk of loved ones being infected as well. The taken measures that aim to slow down the spreading of the virus also come with lots of stressors such as social 
isolation, economic consequences, and un- certainty about the future (Petzold, et al., 2020, p. 1).

As such "people tend to feel anxious and unsafe when the environment changes. In the case of infectious disease outbreaks, when the cause or progression of the disease and outcomes are unclear, rumours grow and close-minded attitudes eventuate" (Usher, Durkin, \& Bhullar, 2020, p. 315).

This has been consistent with one of the articles by Petzold, et al. (2020) which referred to the way the current COVID-19 pandemic does cause psychological distress, anxiety, and depression for large proportions of the general population. Strategies such as maintaining a healthy lifestyle and social contacts, acceptance of anxiety and negative emotions, fostering self-efficacy, and information on where to get medical treatment if needed, seem of help.

Therefore, we must work on finding solutions and increasing awareness of prevention methods and develop self-protection during the coronavirus pandemic (COVID-19). This has been corroborative with one of the studies by McNeely, Schintler, \& Stabile (2020) which has showed that "there is an urgent need for research and policy solutions regarding the impact of the COVID-19, with particular attention to the needs of disadvantaged and vulnerable populations".

At the core of any pandemic response is the ability of authorities and other stakeholders to react appropriately by promoting hygiene and social distancing behaviors. Successfully reaching this goal requires both individual and collective efforts to drastically modify daily routines and activities. There is a need to clarify how knowledge and awareness of disease influence risk perception, and subsequent behavior in the context of pandemics and global outbreaks (Majid, Wasim, Bakshi, \& Truong, 2020, p. 777).

Any precautionary measures, particularly those that protect the individuals during a pandemic reduce anxiety and increase the level of prevention in society. This confirms the findings of one of the researches by Bendau, et al. (2021) which revealed that "specific COVID-19-related anxiety and the average daily amount of preoccupation with the pandemic decreased continuously over the four waves. Unspecific worrying and depressive symptoms decreased on average but not on median level. Self-efficacy, normalization, maintaining social contacts, and knowledge, where to get medical support". 
Also, another article by Usher, Durkin, \& Bhullar (2020) has found that ways to maintain our social connectedness is critical. Lack of interpersonal attachments is linked to poor physical, emotional, and mental health. Setting up regular phone calls or video conferences with family, friends, and colleagues can bridge the gaps brought on by social distancing. As social beings, we need each other. As we are being asked to act in an increasingly unsocial way in order to overcome the challenges of this pandemic, we must remember that we are all in this together and act accordingly (p. 316).

This agrees with another article by Mafugu \& Abel (2020) which has indicated that "the extensive production of face masks, quarantine measures, banning overseas travel, physical distancing, monitoring self-isolating individuals may help to contain the virus".

Also, another article by Spitzer (2020) has found out that face masks can prevent the spread of the virus SARS-CoV-2, in particular as this spread can occur from people with no symptoms. However, covering the lower half of the face reduces the ability to communicate, interpret, and mimic the expressions of those with whom we interact. Positive emotions become less recognizable, and negative emotions are amplified.

In the current issue of coronavirus, increased knowledge of the countries that are failing to contain the pandemic and lessons from countries that were successful in controlling the disease can provide directions on how to effectively deal with the epidemic. Furthermore, the social and environmental surroundings and a person's control over it can be used to predict behavior. Increased knowledge through the use of videos, audios, and text messages in various media platforms may help to modify attitudes, beliefs, and behaviors (Mafugu \& Abel, 2020, p. 110).

Therefore, virtual groups come to play an important role in awareness work, which may help in the development of selfprotection during the coronavirus pandemic (COVID-19).

\section{The study problem is thus focused on responding to the questions:}

1. What are the roles of virtual groups in developing self-protection during the coronavirus pandemic (COVID-19)?

2. What are the tools used by virtual groups to raise awareness of self-protection during the coronavirus pandemic (COVID-19)?

3. What are the obstacles facing virtual groups in developing selfprotection during the coronavirus pandemic (COVID-19)? 
4. What are the suggestions for activating the role of virtual groups in developing self-protection during the coronavirus pandemic (COVID-19)?

\section{Importance of the Study:}

1. The study deals with the subject of self-protection whose importance increases during the coronavirus pandemic (COVID19).

2. Social aspects related with coronavirus pandemic (COVID-19) are one of the focal issues in social work.

3. Group work method needs to dilate the knowledge base of virtual groups.

\section{Study Objectives:}

1. Determining the roles of virtual groups in developing selfprotection during the coronavirus pandemic (COVID-19).

2. Determining the tools used by virtual groups to raise awareness of self-protection during the coronavirus pandemic (COVID-19).

3. Determining the obstacles which facing virtual groups in developing self-protection during the coronavirus pandemic (COVID-19).

4. Reaching the suggestions for activating the role of virtual groups in developing self-protection during the coronavirus pandemic.

Study Hypotheses: The current research attempts to test the major hypothesis: There is a statistically significant correlation between the roles of virtual groups and the tools used by virtual groups to develop self-protection during the Corona pandemic through the following :

First hypothesis: There is a statistically significant correlation between the roles and the tools of virtual groups to enhance selfefficacy during the Corona pandemic.

Second hypothesis: There is a statistically significant correlation between the roles and the tools of virtual groups to protect others during the Corona pandemic.

\section{Study Concept:}

Self-protection during COVID-19 mitigating practices such as 'handwashing', 'social distancing', or 'social isolating' are constructed as 'moral imperatives', required to avert harm to oneself and others. Adherence to COVID-19 mitigating practices is presently high among the general public, and stringent lockdown measures supported by legal and policy intervention have facilitated this. In the coming months, however, as rules are being relaxed and individuals become 
less strict, and thus, the maintenance of recommended social distancing norms will rely on more informal social interactional processes (Prosser, Judge, Bolderdijk, Blackwood, \& Kurz, 2020, p. $653)$.

Thus, the self-protection concept in this study means the combination of measures that will preserve the individual and achieve protection for others such as commitment to social distancing and the preservation of others, and commitment to precautionary measures during the Corona pandemic. The concept of self-protection in this study enhances self-efficacy and protects others.

\section{The virtual groups during Coronavirus pandemic (COVID-19)}

The virtual group means: A number of individuals form a group and communicate virtually, and their group work stages depend on modern technological means as well as the implementation of virtual activities to achieve their goals especially during pandemics.

Coronavirus pandemic (COVID-19): The newly identified novel coronavirus, COVID-19, was first reported in Wuhan, China, in late 2019. The COVID-19 virus is now known to belong to the same family as SARS and Middle East respiratory syndrome coronavirus (MERS-COV). The virus has rapidly spread across the globe leading to many infected people and multiple deaths, especially of the elderly and vulnerable (Usher, Durkin, \& Bhullar, 2020, p. 315).

The novel Corona virus COVID - 19 viral disease has threatened the world. The WHO has already declared on March 11, 2020 this as a global pandemic in nearly 200 countries. At that time, WHO has advised all countries to take a whole $=$ of $=$ government, whole $=$ ofsociety approach, built around a comprehensive strategy to prevent infection, save lives and minimize the impact (Gopinath, 2020, p. 1).

"The coronavirus pandemic poses a challenge for different societies, and their respective cultures, as it reveals how differently people react and regulate themselves according to this frantic situation" (Scalabrini, Xu, \& Northoff, 2021, p. 37). "The COVID-19 pandemic is a highly dynamic situation where mental health consequences might change rapidly due to, for example, changing case numbers, changing governmental restrictions, habituation or change in media coverage"_(Bendau, et al., 2021, p. 2). 


\section{Methodological Procedures:}

This study belongs to the descriptive and analytical studies that aim to determine the characteristics of a specific problem and examine its surrounding conditions. A social survey is used to collect social data through questionnaires which are given to students who are members in virtual groups in the College of Arts and Social Science, Sultan Qaboos University, during the period from March 2021 until May 2021.

Target population: includes all students in virtual groups in the College of Arts and Social Science, Sultan Qaboos University, who practiced the activities through technological means and communicated electronically especially during the Corona pandemic.

- The study tool has been distributed to all students by electronic accounts of virtual groups, but we have obtained 63 responses only. Hence, this study relies on available subjects sampling.

- The sample shows non-probability, so the results cannot be a generalization for research population. However, these results have shown indicators which will guide other studies in the future.

\section{Study Tools:}

This study relies on electronic questionnaires which are divided into five axes: (a) the basic data, (b) the roles of virtual groups in developing self-protection from the Corona pandemic, (c) the tools used by virtual groups to raise awareness of self-protection during the Corona pandemic, (d) the obstacles facing virtual groups in developing self-protection during the Corona pandemic, (e) the suggestions for activating the role of virtual groups in developing selfprotection during the Corona pandemic.

Validity: The questionnaire was administered to four social work experts to judge the questionnaires and express their opinion about the appropriateness of each statement regarding its formulation and its relevance to the dimension to be measured. They were free to add suitable statements, delete others and modify some with respect to the formulation. Answers to each statement are presented by selecting one of the three answers (I agree- I somewhat agree - I do not agree).

Reliability: The coefficient of stability Alpha-Cronbach was used to ensure reliability, and its outcome $=0.782$. This result indicates an acceptable degree of reliability; therefore, this tool can be relied upon. 


\section{Results}

Table (1) shows gender $(\mathrm{N}=63)$

\begin{tabular}{|c||c||c||c|}
\hline $\mathrm{N}$ & gender & Frequency & Percent \\
\hline \hline 1 & Males & 17 & 27 \\
\hline \hline 2 & Females & 46 & 73 \\
\hline \hline \multicolumn{2}{||}{ Total } & 63 & 100 \\
\hline
\end{tabular}

This table shows gender which indicates that the largest percentage was for females with $73 \%$ and for the males with a percentage of $27 \%$.

Table (2) shows the region of residence $(\mathrm{N}=63)$

\begin{tabular}{|c|c|c|c|}
\hline $\mathrm{N}$ & Region of residence & Frequency & Percent \\
\hline 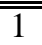 & $\begin{array}{ll}\text { Rural } \\
\end{array}$ & 26 & \begin{tabular}{c|}
41.3 \\
\end{tabular} \\
\hline 2 & Urban & 22 & 34.9 \\
\hline 3 & Badia & 4 & 6.3 \\
\hline 4 & Coastal & 11 & 17.5 \\
\hline \multicolumn{2}{|r|}{ Total } & 63 & 100 \\
\hline
\end{tabular}

This table shows the region of residence indicating the "rural" with a percentage of $41.3 \%$, the "urban" with $34.9 \%$, the "coastal" with $17.5 \%$, and the "Badia" with a percentage of $6.3 \%$.

Table (3) shows the academic year $(\mathrm{N}=63)$

\begin{tabular}{|c||c||c||c||}
\hline $\mathrm{N}$ & Academic year & Frequency & Percent \\
\hline \hline 1 & The first & 1 & 1.6 \\
\hline \hline 3 & The second & 4 & 6.3 \\
\hline \hline 4 & The third & 25 & 39.7 \\
\hline \hline 5 & The fourth & 19 & 30.2 \\
\hline \hline 6 & The fifth & 10 & 15.9 \\
\hline \hline
\end{tabular}

This table shows the academic year. The largest percentage was for "the third" and "the fourth" with $69.9 \%$, "the fifth" with $15.9 \%$, "the second" and "the sixth" with the same percentage of $6.3 \%$, and the lowest percentage was for "the first" with $1.6 \%$.

Table (4) shows name of the groups $(\mathrm{N}=63)$

\begin{tabular}{|c|c|c|c|}
\hline $\mathrm{N}$ & Groups & Frequency & Percent \\
\hline 1 & $\begin{array}{c}\text { Group College of Arts and } \\
\text { Social Sciences } \\
\end{array}$ & 2 & 3.2 \\
\hline 2 & Insight Creativity Group & 9 & 14.3 \\
\hline 3 & Media Creativity Group & 3 & 4.8 \\
\hline 4 & Geography Group & 6 & 9.5 \\
\hline$\overline{5}$ & Social work group & 32 & $\overline{c 50.8}$ \\
\hline 6 & Social Vision Group & 8 & 12.7 \\
\hline 7 & Tourism group & $\overline{20}$ & 3.2 \\
\hline 8 & Arabic Tongue Group & 1 & 1.6 \\
\hline & Total & 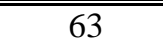 & 100 \\
\hline
\end{tabular}




\begin{tabular}{|lr||}
\hline Egyptian Journal of Social Work (EJSW) & http://ejsw.journals.ekb.eg \\
ISSN: 2356-9204 & Vol 13, Issue 1, January 2022 \\
\hline
\end{tabular}

This table shows name of the groups indicating the largest percentage for "social work group" with 50.8\%, "Insight Creativity Group" with a percentage of $14.3 \%$, "Social Vision Group" with 12.7\%, "Geography Group" with 9.5\%, "Media Creativity Group" with $4.8 \%$, "Group College of Arts and Social Sciences" and "Tourism group" with the same percentage of $3.2 \%$, and the lowest percentage was for "Arabic Tongue Group" with $1.6 \%$.

Table (5) shows the roles of virtual groups in developing selfprotection from the Corona pandemic $(\mathrm{N}=63)$

\begin{tabular}{|c|c|c|c|c|c|c|c|c|c|c|c|}
\hline \multirow[b]{3}{*}{$\mathrm{N}$} & \multirow{3}{*}{$\begin{array}{l}\text { The roles of } \\
\text { virtual group }\end{array}$} & \multicolumn{6}{|c|}{ Responses } & \multirow{3}{*}{$\begin{array}{l}\frac{n}{0} \\
\cdot \frac{00}{0} \\
3 \\
\frac{\pi}{0} \\
0\end{array}$} & \multirow{3}{*}{ 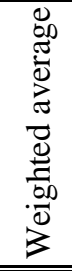 } & \multirow{3}{*}{ 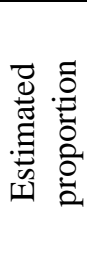 } & \multirow{3}{*}{$\frac{\stackrel{\infty}{\Xi}}{\stackrel{\Xi}{\Xi}}$} \\
\hline & & \multicolumn{2}{|c|}{ yes } & \multicolumn{2}{|c|}{ sometimes } & \multicolumn{2}{|c|}{ No } & & & & \\
\hline & & 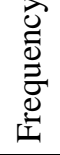 & $\%$ & 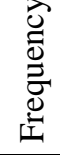 & $\%$ & 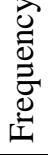 & $\%$ & & & & \\
\hline 1 & $\begin{array}{l}\text { they } \\
\text { emphasize } \\
\text { social } \\
\text { distancing } \\
\text { adherence }\end{array}$ & 34 & 54 & 29 & 46 & 0 & 0 & 160 & 2.5 & 84.7 & 4 \\
\hline 2 & $\begin{array}{l}\text { they increase } \\
\text { awareness on } \\
\text { safety and } \\
\text { security } \\
\text { procedures } \\
\text { against } \\
\text { infection } \\
\text { with the } \\
\text { Coronavirus }\end{array}$ & 47 & 74.6 & 16 & 25.4 & 0 & 0 & 173 & 2.7 & 91.5 & 1 \\
\hline 3 & $\begin{array}{l}\text { they increase } \\
\text { awareness on } \\
\text { maintaining } \\
\text { the safety for } \\
\text { others during } \\
\text { the } \\
\text { Coronavirus } \\
\text { pandemic }\end{array}$ & 40 & 63.5 & 17 & 27 & 6 & 9.5 & 160 & 2.5 & 84.7 & 4 \\
\hline 4 & $\begin{array}{l}\text { they raise } \\
\text { awareness on } \\
\text { protection } \\
\text { when a } \\
\text { family } \\
\text { member gets } \\
\text { infected with } \\
\text { Coronavirus }\end{array}$ & 33 & 52.4 & 27 & 42.9 & 3 & 4.8 & 156 & 2.48 & 82.5 & 6 \\
\hline
\end{tabular}




\begin{tabular}{|lr||}
\hline $\begin{array}{l}\text { Egyptian Journal of Social Work (EJSW) } \\
\text { ISSN: 2356-9204 }\end{array}$ & hol 13, Issue 1, January 2022 \\
\hline \hline
\end{tabular}

\begin{tabular}{|c|c|c|c|c|c|c|c|c|c|c|c|}
\hline \multirow[b]{3}{*}{$\mathrm{N}$} & \multirow{3}{*}{$\begin{array}{l}\text { The roles of } \\
\text { virtual group }\end{array}$} & \multicolumn{6}{|c|}{$\begin{array}{l}\text { Responses } \\
\end{array}$} & \multirow{3}{*}{ 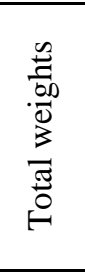 } & \multirow{3}{*}{ 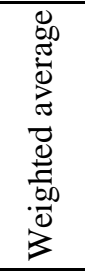 } & \multirow{3}{*}{ 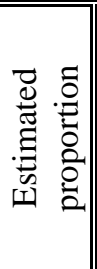 } & \multirow{3}{*}{ 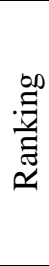 } \\
\hline & & \multicolumn{2}{|c|}{ yes } & \multicolumn{2}{|c|}{ sometimes } & \multicolumn{2}{|c|}{ No } & & & & \\
\hline & & 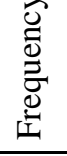 & $\%$ & 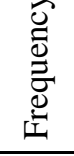 & $\%$ & 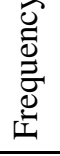 & $\%$ & & & & \\
\hline 5 & $\begin{array}{l}\text { they provide } \\
\text { opportunities } \\
\text { to participate } \\
\text { in virtual } \\
\text { activities }\end{array}$ & 46 & 73 & 17 & 27 & 0 & 0 & 172 & 2.7 & 91 & 2 \\
\hline 6 & $\begin{array}{l}\text { they increase } \\
\text { the } \\
\text { knowledge } \\
\text { about the } \\
\text { problems } \\
\text { related to the } \\
\text { Coronavirus }\end{array}$ & 24 & 38.1 & 31 & 49.2 & 8 & 12.7 & 142 & 2.25 & 75.1 & 10 \\
\hline 7 & $\begin{array}{l}\text { they } \\
\text { emphasize } \\
\text { that facing } \\
\text { the pandemic } \\
\text { is everyone's } \\
\text { responsibility }\end{array}$ & 39 & 61.9 & 24 & 38.1 & 0 & 0 & 165 & 2.6 & 87.3 & 3 \\
\hline 8 & $\begin{array}{l}\text { they help } \\
\text { people learn } \\
\text { how to } \\
\text { organize } \\
\text { time during } \\
\text { Coronavirus } \\
\end{array}$ & 29 & 46 & 31 & 49.2 & 3 & 4.8 & 152 & 2.4 & 80.4 & 7 \\
\hline 9 & $\begin{array}{l}\text { they reduce } \\
\text { the fear and } \\
\text { panic of } \\
\text { infection } \\
\text { with } \\
\text { Coronavirus }\end{array}$ & 25 & 39.7 & 34 & 54 & 4 & 6.3 & 147 & 2.3 & 77.8 & 9 \\
\hline 10 & $\begin{array}{l}\text { they limit the } \\
\text { spread of } \\
\text { rumours } \\
\text { related to the } \\
\text { Corona } \\
\text { pandemic }\end{array}$ & 29 & 46 & 27 & 42.9 & 7 & 11.1 & 148 & 2.35 & 78.3 & 8 \\
\hline & Total & 346 & 54.9 & 253 & 40.2 & 31 & 4.9 & 1575 & 2.5 & 83 & \\
\hline
\end{tabular}




\begin{tabular}{|lr||}
\hline Egyptian Journal of Social Work (EJSW) & http://ejsw.journals.ekb.eg \\
ISSN: $2356-9204$ & Vol 13, Issue 1, January 2022 \\
\hline
\end{tabular}

This table shows the roles of virtual groups in developing selfprotection from the Corona pandemic such as: "they increase awareness on safety and security procedures against infection with the Coronavirus", which came in the first ranking with a percentage of 91.5\%. In the second ranking came "they provide opportunities to participate in virtual activities" with percentage of $91 \%$. In the third ranking came "they emphasize that facing the pandemic is everyone's responsibility" with a percentage of $87.3 \%$. In the fourth ranking came "they emphasize social distancing adherence" and " they increase awareness on maintaining the safety for others during the Coronavirus pandemic" with a percentage of $84.7 \%$. In the sixth ranking came "they raise awareness on protection when a family member gets infected with Coronavirus" with percentage of $82.5 \%$. In the seventh ranking came "they help people learn how to organize time during Coronavirus" with a percentage of $80.4 \%$. In the eighth ranking came "they limit the spread of rumours related to the Corona pandemic" with a percentage of $78.3 \%$. In the ninth ranking came "they reduce the fear and panic of infection with Coronavirus" with a percentage of $77.8 \%$. Finally, in the tenth ranking came "they increase the knowledge about the problems related to the Coronavirus" with a percentage of $75.1 \%$.

Table (6) shows the tools used by virtual groups to raise awareness of self-protection during the Corona pandemic $(\mathrm{N}=63)$

\begin{tabular}{|c|c|c|c|c|c|c|c|c|c|c|c|}
\hline \multirow[b]{3}{*}{$\mathrm{N}$} & \multirow[b]{3}{*}{ The tools } & \multicolumn{6}{|c|}{ Responses } & \multirow{3}{*}{$\begin{array}{l}0 \\
\frac{0}{600} \\
00 \\
03 \\
\frac{5}{0} \\
0\end{array}$} & \multirow{3}{*}{ 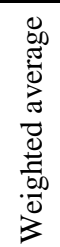 } & \multirow{3}{*}{ 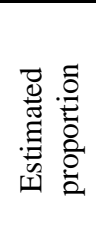 } & \multirow{3}{*}{ 泀 } \\
\hline & & \multicolumn{2}{|c|}{ yes } & \multicolumn{2}{|c|}{ sometimes } & \multicolumn{2}{|c|}{ No } & & & & \\
\hline & & 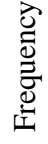 & $\%$ & 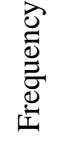 & $\%$ & 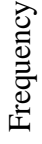 & $\%$ & & & & \\
\hline 1 & $\begin{array}{l}\text { Virtual lectures } \\
\text { on methods of } \\
\text { self-protection } \\
\text { during a } \\
\text { pandemic }\end{array}$ & 19 & 30.2 & 34 & 54 & 10 & 15.9 & 135 & 2.1 & 71.4 & 5 \\
\hline 2 & $\begin{array}{l}\text { Group } \\
\text { discussions } \\
\text { through social } \\
\text { media about } \\
\text { prevention } \\
\text { procedures } \\
\text { during a } \\
\text { pandemic }\end{array}$ & 20 & 31.7 & 33 & 52.4 & 10 & 15.9 & 136 & 2.2 & 71.96 & 4 \\
\hline
\end{tabular}




\begin{tabular}{||lr||}
\hline \hline Egyptian Journal of Social Work (EJSW) & http://ejsw.journals.ekb.eg \\
ISSN: 2356-9204 & Vol 13, Issue 1, January 2022 \\
\hline \hline
\end{tabular}

\begin{tabular}{|c|c|c|c|c|c|c|c|c|c|c|c|}
\hline \multirow[b]{3}{*}{$\mathrm{N}$} & \multirow[b]{3}{*}{ The tools } & \multicolumn{6}{|c|}{ Responses } & \multirow{3}{*}{ 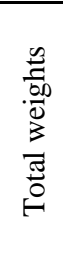 } & \multirow{3}{*}{ 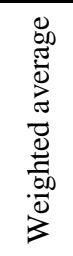 } & \multirow{3}{*}{ 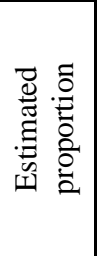 } & \multirow{3}{*}{ : } \\
\hline & & \multicolumn{2}{|c|}{ yes } & \multicolumn{2}{|c|}{ sometimes } & \multicolumn{2}{|c|}{ No } & & & & \\
\hline & & 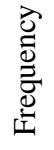 & $\%$ & 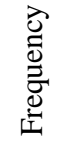 & $\%$ & 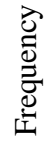 & $\%$ & & & & \\
\hline 3 & $\begin{array}{l}\text { Virtual } \\
\text { meetings with } \\
\text { specialists for } \\
\text { dealing with the } \\
\text { problems } \\
\text { related to the } \\
\text { pandemic }\end{array}$ & 18 & 28.6 & 26 & 41.3 & 19 & 30.2 & 125 & 1.98 & 66.1 & 6 \\
\hline 4 & $\begin{array}{l}\text { publishing } \\
\text { posters in social } \\
\text { networking } \\
\text { accounts in } \\
\text { order to } \\
\text { emphasize self- } \\
\text { protection } \\
\text { during the } \\
\text { pandemic }\end{array}$ & 34 & 54 & 17 & 27 & 12 & 19 & 148 & 2.35 & 78.3 & 2 \\
\hline 5 & $\begin{array}{l}\text { Videos raising } \\
\text { awareness } \\
\text { about the } \\
\text { pandemic }\end{array}$ & 32 & 50.8 & 22 & 34.9 & 9 & 14.3 & 149 & 2.37 & 78.8 & 1 \\
\hline 6 & $\begin{array}{l}\text { Virtual } \\
\text { interviews with } \\
\text { the recovered } \\
\text { from the } \\
\text { coronavirus }\end{array}$ & 15 & 23.8 & 17 & 27 & 31 & 49.2 & 110 & 1.7 & 58.2 & 7 \\
\hline 7 & $\begin{array}{l}\text { Virtual } \\
\text { meetings to } \\
\text { organize } \\
\text { working in the } \\
\text { group } \\
\end{array}$ & 25 & 39.7 & 34 & 54 & 4 & 6.3 & 147 & 2.3 & 77.8 & 3 \\
\hline & Total & 163 & 37 & 183 & 41.5 & 95 & 21.5 & 950 & 2.2 & 71. & \\
\hline
\end{tabular}

This table shows the tools used by virtual groups to raise awareness of self-protection during the Corona pandemic such as: "videos raising awareness about the pandemic", which came in the first ranking with a percentage of $78.8 \%$. The second ranking is "publishing posters in social networking accounts in order to emphasize self-protection during the pandemic" with a percentage of $78.3 \%$. The third ranking is "virtual meetings to organize working in the group" with a percentage of $77.8 \%$. The fourth ranking is "group discussions through social media about prevention procedures during a pandemic" with a percentage of $71.96 \%$. The fifth ranking is "virtual lectures on 


\begin{tabular}{|lr||}
\hline Egyptian Journal of Social Work (EJSW) & http://ejsw.journals.ekb.eg \\
ISSN: $2356-9204$ & Vol 13, Issue 1, January 2022 \\
\hline
\end{tabular}

methods of self-protection during a pandemic" with a percentage of $71.4 \%$. The sixth ranking is "virtual meetings with specialists for dealing with the problems related to the pandemic" with a percentage of $66.1 \%$. The seventh ranking is "virtual interviews with the recovered from the Coronavirus" with a percentage of 58.2\%.

Table (7) shows the obstacles facing virtual groups in developing self-protection during the Corona pandemic $(N=63)$

\begin{tabular}{|c|c|c|c|c|c|c|c|c|c|c|c|}
\hline \multirow[b]{3}{*}{$\mathrm{N}$} & \multirow[b]{3}{*}{ The obstacles } & \multicolumn{6}{|c|}{ Responses } & \multirow{3}{*}{$\begin{array}{l}\stackrel{0}{0} \\
\frac{0}{00} \\
0 \\
\frac{1}{0} \\
0 \\
0\end{array}$} & \multirow{3}{*}{ 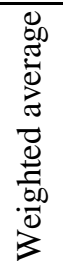 } & \multirow{3}{*}{ 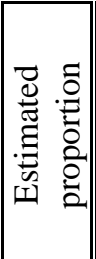 } & \multirow{3}{*}{ 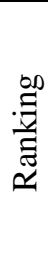 } \\
\hline & & \multicolumn{2}{|c|}{ yes } & \multicolumn{2}{|c|}{ sometimes } & \multicolumn{2}{|c|}{ No } & & & & \\
\hline & & 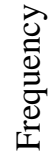 & $\%$ & 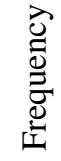 & $\%$ & 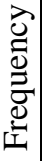 & $\%$ & & & & \\
\hline 1 & $\begin{array}{l}\text { the lack of } \\
\text { collective } \\
\text { creativity during } \\
\text { the Corona } \\
\text { pandemic }\end{array}$ & 30 & $\begin{array}{l}47 \\
.6\end{array}$ & 27 & 42.9 & 6 & $\begin{array}{l}9 . \\
5\end{array}$ & $\begin{array}{c}15 \\
0\end{array}$ & 2.4 & $\begin{array}{c}79 . \\
4\end{array}$ & 6 \\
\hline 2 & $\begin{array}{l}\text { Isolation when } \\
\text { implementing the } \\
\text { program of virtual } \\
\text { group during the } \\
\text { pandemic }\end{array}$ & 38 & $\begin{array}{c}60 \\
.3\end{array}$ & 22 & 34.9 & 3 & $\begin{array}{c}4 . \\
8\end{array}$ & $\begin{array}{c}16 \\
1\end{array}$ & 2.6 & $\begin{array}{c}85 . \\
2\end{array}$ & 3 \\
\hline 3 & $\begin{array}{l}\text { insufficient } \\
\text { activities due to the } \\
\text { lack of direct } \\
\text { interaction between } \\
\text { the group members }\end{array}$ & 54 & $\begin{array}{l}85 \\
.7\end{array}$ & 9 & 14.3 & 0 & 0 & $\begin{array}{c}18 \\
0\end{array}$ & 2.9 & $\begin{array}{l}95 . \\
2\end{array}$ & 1 \\
\hline 4 & $\begin{array}{l}\text { The feeling of } \\
\text { having marginal } \\
\text { relationships with } \\
\text { colleagues in the } \\
\text { virtual group } \\
\text { during the } \\
\text { pandemic }\end{array}$ & 30 & $\begin{array}{l}47 \\
.6\end{array}$ & 33 & 52.4 & 0 & 0 & $\begin{array}{c}15 \\
6\end{array}$ & $\begin{array}{c}2.4 \\
8\end{array}$ & $\begin{array}{c}82 . \\
5\end{array}$ & 4 \\
\hline 5 & $\begin{array}{l}\text { Poor coordination } \\
\text { during the } \\
\text { preparation for } \\
\text { virtual group } \\
\text { activities } \\
\end{array}$ & 29 & 46 & 31 & 49.2 & 3 & $\begin{array}{c}4 . \\
8\end{array}$ & $\begin{array}{c}15 \\
2\end{array}$ & 2.4 & $\begin{array}{c}80 . \\
4\end{array}$ & 5 \\
\hline 6 & $\begin{array}{l}\text { Not having } \\
\text { sufficient } \\
\text { electronic skills } \\
\text { that help to interact } \\
\text { with the group and }\end{array}$ & 29 & 46 & 21 & 33.3 & $\begin{array}{l}1 \\
3\end{array}$ & $\begin{array}{c}20 \\
.6\end{array}$ & $\begin{array}{c}14 \\
2\end{array}$ & $\begin{array}{c}2.2 \\
5\end{array}$ & $\begin{array}{c}75 . \\
1\end{array}$ & 7 \\
\hline
\end{tabular}




\begin{tabular}{|lr||}
\hline Egyptian Journal of Social Work (EJSW) & http://ejsw.journals.ekb.eg \\
ISSN: 2356-9204 & Vol 13, Issue 1, January 2022 \\
\hline
\end{tabular}

\begin{tabular}{|c|c|c|c|c|c|c|c|c|c|c|c|}
\hline \multirow[b]{3}{*}{$\mathrm{N}$} & \multirow[b]{3}{*}{ The obstacles } & \multicolumn{6}{|c|}{ Responses } & \multirow{3}{*}{ 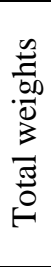 } & \multirow{3}{*}{ 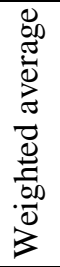 } & \multirow{3}{*}{ 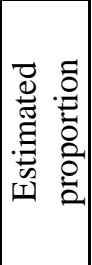 } & \multirow{3}{*}{ 先 } \\
\hline & & \multicolumn{2}{|c|}{ yes } & \multicolumn{2}{|c|}{ sometimes } & \multicolumn{2}{|c|}{ No } & & & & \\
\hline & & 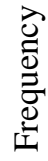 & $\%$ & 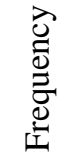 & $\%$ & 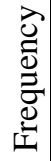 & $\%$ & & & & \\
\hline & $\begin{array}{l}\text { achieve its } \\
\text { programs and goals }\end{array}$ & & & & & & & & & & \\
\hline 7 & $\begin{array}{l}\text { Students are busy } \\
\text { due to the e- } \\
\text { learning stresses } \\
\text { during the } \\
\text { pandemic }\end{array}$ & 50 & $\begin{array}{l}79 \\
.4\end{array}$ & 13 & 20.6 & 0 & 0 & $\begin{array}{c}17 \\
6\end{array}$ & 2.8 & $\begin{array}{c}93 . \\
1\end{array}$ & 2 \\
\hline & Total & $\begin{array}{c}26 \\
0\end{array}$ & 59 & 156 & 35.4 & $\begin{array}{l}2 \\
5\end{array}$ & $\begin{array}{l}5 . \\
6\end{array}$ & $\begin{array}{l}11 \\
17\end{array}$ & 2.5 & 84 & \\
\hline
\end{tabular}

This table shows the obstacles facing virtual groups in developing self-protection during the Corona pandemic such as: "insufficient activities due to the lack of direct interaction between the group members" which came in the first ranking with a percentage of $95.2 \%$. In the second ranking came "students are busy due to the e-learning stresses during the pandemic" with a percentage of $93.1 \%$. In the third ranking came "isolation when implementing the program of virtual group during the pandemic" with a percentage of $85.2 \%$. In the fourth ranking came "the feeling of having marginal relationships with colleagues in the virtual group during the pandemic" with a percentage of $82.5 \%$. In the fifth ranking came "poor coordination during the preparation for virtual group activities" with a percentage of $80.4 \%$. In the sixth ranking came "the lack of collective creativity during the Corona pandemic" with a percentage of $79.4 \%$. In the seventh ranking came "not having sufficient electronic skills that help to interact with the group and achieve its programs and goals" with a percentage of $75.1 \%$. 


\begin{tabular}{|lr||}
\hline $\begin{array}{l}\text { Egyptian Journal of Social Work (EJSW) } \\
\text { ISSN: 2356-9204 }\end{array}$ & hol 13, Issue 1, January 2022 \\
\hline \hline
\end{tabular}

Table (8) shows suggestions for activating the role of virtual groups in developing self-protection during the Corona pandemic $(\mathrm{N}=63)$

\begin{tabular}{|c|c|c|c|c|c|c|c|c|c|c|c|}
\hline \multirow[b]{3}{*}{$\mathrm{N}$} & \multirow[b]{3}{*}{$\begin{array}{c}\text { The } \\
\text { suggestions }\end{array}$} & \multicolumn{6}{|c|}{ Responses } & \multirow{3}{*}{ 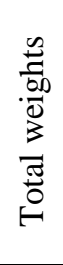 } & \multirow{3}{*}{ 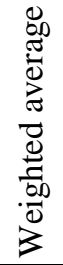 } & \multirow{3}{*}{ 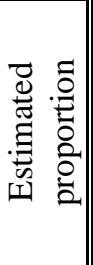 } & \multirow{3}{*}{ 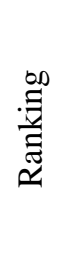 } \\
\hline & & \multicolumn{2}{|c|}{ yes } & \multicolumn{2}{|c|}{ sometimes } & \multicolumn{2}{|c|}{ No } & & & & \\
\hline & & 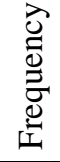 & $\%$ & 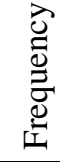 & $\%$ & 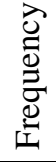 & $\%$ & & & & \\
\hline 1 & $\begin{array}{l}\text { Holding } \\
\text { workshops to } \\
\text { help the youth } \\
\text { for qualifying } \\
\text { and dealing } \\
\text { with crises } \\
\text { such as the } \\
\text { Corona } \\
\text { pandemic }\end{array}$ & 50 & 79.4 & 13 & 20.6 & 0 & 0 & 176 & 2.8 & 93.1 & 4 \\
\hline 2 & $\begin{array}{l}\text { Establishing a } \\
\text { training } \\
\text { program to } \\
\text { develop the } \\
\text { electronic } \\
\text { skills for the } \\
\text { members }\end{array}$ & 51 & 81 & 12 & 19 & 0 & 0 & 177 & 2.8 & 93.7 & 2 \\
\hline 3 & $\begin{array}{l}\text { Setting } \\
\text { heuristic } \\
\text { guidelines to } \\
\text { help virtual } \\
\text { groups find a } \\
\text { creative } \\
\text { environment } \\
\text { during } \\
\text { pandemics } \\
\end{array}$ & 47 & 74.6 & 16 & 25.4 & 0 & 0 & 173 & 2.7 & 91.5 & 6 \\
\hline 4 & $\begin{array}{l}\text { Encouraging } \\
\text { the members } \\
\text { to volunteer } \\
\text { electronically } \\
\text { during the } \\
\text { Corona } \\
\text { pandemic } \\
\end{array}$ & 56 & 88.9 & 7 & 11.1 & 0 & 0 & 182 & 2.9 & 96.3 & 1 \\
\hline 5 & $\begin{array}{l}\text { Increasing the } \\
\text { role of } \\
\text { awareness to } \\
\text { achieve } \\
\text { prevention }\end{array}$ & 48 & 76.2 & 15 & 23.8 & 0 & 0 & 174 & 2.8 & 92.1 & 5 \\
\hline
\end{tabular}




\begin{tabular}{|lr||}
\hline Egyptian Journal of Social Work (EJSW) & http://ejsw.journals.ekb.eg \\
ISSN: 2356-9204 & Vol 13, Issue 1, January 2022 \\
\hline \hline
\end{tabular}

\begin{tabular}{|c|c|c|c|c|c|c|c|c|c|c|c|}
\hline \multirow[b]{3}{*}{$\mathrm{N}$} & \multirow{3}{*}{$\begin{array}{c}\text { The } \\
\text { suggestions }\end{array}$} & \multicolumn{6}{|c|}{ Responses } & \multirow{3}{*}{ 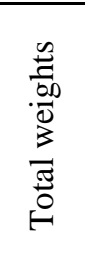 } & \multirow{3}{*}{ 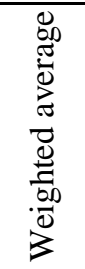 } & \multirow{3}{*}{ 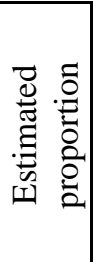 } & \multirow{3}{*}{ 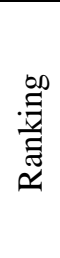 } \\
\hline & & \multicolumn{2}{|c|}{ yes } & \multicolumn{2}{|c|}{ sometimes } & \multicolumn{2}{|c|}{ No } & & & & \\
\hline & & 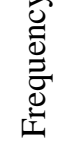 & $\%$ & 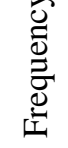 & $\%$ & 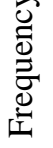 & $\%$ & & & & \\
\hline & $\begin{array}{l}\text { and self- } \\
\text { protection } \\
\text { during } \\
\text { pandemics }\end{array}$ & & & & & & & & & & \\
\hline 6 & $\begin{array}{l}\text { Transferring } \\
\text { the scientific } \\
\text { expertise } \\
\text { from } \\
\text { specialists } \\
\text { about self- } \\
\text { protection } \\
\text { during the } \\
\text { Corona } \\
\text { pandemic }\end{array}$ & 35 & 55.6 & 28 & 44.4 & 0 & 0 & 161 & 2.6 & 85.2 & 7 \\
\hline 7 & $\begin{array}{l}\text { Disseminating } \\
\text { the initiatives } \\
\text { related to } \\
\text { dealing with } \\
\text { the pandemic }\end{array}$ & 51 & 81 & 12 & 19 & 0 & 0 & 177 & 2.8 & 93.7 & 2 \\
\hline & "Total & 338 & 76.6 & 103 & 23.4 & 0 & 0 & 1220 & 2.77 & 92. & \\
\hline
\end{tabular}

This table shows the suggestions for activating the role of virtual groups in developing self-protection during the Corona pandemic such as: "encouraging the members to volunteer electronically during the Corona pandemic", which came in the first ranking with a percentage of $96.3 \%$ In the second ranking came "establishing a training program to develop the electronic skills for the members" and "disseminating the initiatives related to dealing with the pandemic" with the same percentage of $93.7 \%$. In the fourth ranking came "holding workshops to help the youth for qualifying and dealing with crises such as the Corona pandemic" with a percentage of $93.1 \%$ In the fifth ranking came "increasing the role of awareness to achieve prevention and selfprotection during pandemics" with a percentage of $92.1 \%$. In the sixth ranking came "setting heuristic guidelines to help virtual groups find a creative environment during pandemics" with a percentage of $91.5 \%$. In the seventh ranking "transferring the scientific expertise from specialists about self-protection during the Corona pandemic" with a percentage of $85.2 \%$. 
Table (9) shows the correlation between the roles and the tools of virtual groups to enhance self-efficacy during the Corona pandemic $(\mathrm{N}=63)$

\begin{tabular}{|c|c|c|}
\hline Roles & $\begin{array}{l}\text { Spearman's } \\
\text { rho }\end{array}$ & $\begin{array}{l}\text { publishing posters in } \\
\text { social networking } \\
\text { accounts } \\
\end{array}$ \\
\hline \multirow{2}{*}{$\begin{array}{l}\text { they emphasize social distancing } \\
\text { adherence }\end{array}$} & $\begin{array}{l}\text { Correlation } \\
\text { Coefficient }\end{array}$ & $.377^{* *}$ \\
\hline & Sig. & .002 \\
\hline Tools & $\begin{array}{l}\text { Spearman's } \\
\text { rho }\end{array}$ & $\begin{array}{l}\text { Virtual interviews with } \\
\text { the recovered from the } \\
\text { coronavirus }\end{array}$ \\
\hline \multirow{2}{*}{$\begin{array}{l}\text { they emphasize social distancing } \\
\text { adherence }\end{array}$} & $\begin{array}{l}\text { Correlation } \\
\text { Coefficient }\end{array}$ & $.380^{* *}$ \\
\hline & Sig. & .002 \\
\hline Roles & $\begin{array}{l}\text { Spearman's } \\
\text { rho }\end{array}$ & $\begin{array}{l}\text { publishing posters in } \\
\text { social networking } \\
\text { accounts }\end{array}$ \\
\hline \multirow{2}{*}{$\begin{array}{l}\text { they increase awareness on safety and } \\
\text { security procedures against infection } \\
\text { with the Coronavirus }\end{array}$} & $\begin{array}{l}\text { Correlation } \\
\text { Coefficient } \\
\end{array}$ & $.680^{* *}$ \\
\hline & Sig. & .000 \\
\hline Tools & $\begin{array}{l}\text { Spearman's } \\
\text { rho }\end{array}$ & $\begin{array}{c}\text { Videos raising awareness } \\
\text { about the pandemic }\end{array}$ \\
\hline \multirow{2}{*}{$\begin{array}{l}\text { they increase awareness on safety and } \\
\text { security procedures against infection } \\
\text { with the Coronavirus }\end{array}$} & $\begin{array}{l}\text { Correlation } \\
\text { Coefficient }\end{array}$ & $.536^{* *}$ \\
\hline & Sig. & $\begin{array}{c}.000 \\
\end{array}$ \\
\hline Roles & $\begin{array}{l}\text { Spearman's } \\
\text { rho }\end{array}$ & $\begin{array}{l}\text { Virtual meetings to } \\
\text { organize working in the } \\
\text { group } \\
\end{array}$ \\
\hline \multirow[t]{2}{*}{$\begin{array}{l}\text { they provide opportunities to } \\
\text { participate in virtual activities }\end{array}$} & $\begin{array}{l}\text { Correlation } \\
\text { Coefficient } \\
\end{array}$ & $.370^{* *}$ \\
\hline & Sig. & .003 \\
\hline Roles & $\begin{array}{l}\text { Spearman's } \\
\text { rho }\end{array}$ & $\begin{array}{l}\text { Virtual interviews with } \\
\text { the recovered from the } \\
\text { coronavirus }\end{array}$ \\
\hline \multirow{2}{*}{$\begin{array}{l}\text { they help people learn how to } \\
\text { organize time during Coronavirus }\end{array}$} & $\begin{array}{l}\text { Correlation } \\
\text { Coefficient }\end{array}$ & $.331^{* *}$ \\
\hline & Sig. & .008 \\
\hline
\end{tabular}

The above-mentioned table shows that there is a statistically significant correlation between the roles and the tools of virtual groups to enhance self-efficacy during the Corona pandemic because there has been a weak positive correlation between: "they emphasize social 


\begin{tabular}{|lr||}
\hline Egyptian Journal of Social Work (EJSW) & http://ejsw.journals.ekb.eg \\
ISSN: 2356-9204 & Vol 13, Issue 1, January 2022 \\
\hline \hline
\end{tabular}

distancing adherence" and "publishing posters in social networking accounts" and also, with "virtual interviews with the recovered from the Coronavirus". Similarly, there has been a strong positive correlation between: "they increase awareness on safety and security procedures against infection with the Coronavirus" and "publishing posters in social networking accounts " and also, there has been moderate positive correlation between this role and "videos raising awareness about the pandemic".

In the same way, there has a been weak positive correlation between: "they provide opportunities to participate in virtual activities" and "virtual meetings to organize working in the group". Along the same line, there has been a weak positive correlation between: "they help people learn how to organize time during the Coronavirus pandemic" and "virtual interviews with the recovered from the Coronavirus".

\section{Table (10) shows the correlation between the roles and the tools of virtual groups to protect others during the Corona pandemic $(\mathrm{N}=63)$}

\begin{tabular}{|c|c|c|}
\hline Roles & $\begin{array}{l}\text { Spearman's } \\
\text { rho }\end{array}$ & $\begin{array}{c}\text { Virtual lectures on methods of } \\
\text { self-protection during a } \\
\text { pandemic }\end{array}$ \\
\hline \multirow{2}{*}{$\begin{array}{l}\text { they increase awareness on } \\
\text { maintaining the safety for others } \\
\text { during the Coronavirus pandemic }\end{array}$} & $\begin{array}{l}\text { Correlation } \\
\text { Coefficient }\end{array}$ & $.487^{* *}$ \\
\hline & Sig. & .000 \\
\hline Tools & $\begin{array}{l}\text { Spearman's } \\
\text { rho }\end{array}$ & $\begin{array}{l}\text { Group discussions through } \\
\text { social media }\end{array}$ \\
\hline \multirow{2}{*}{$\begin{array}{l}\text { they increase awareness on } \\
\text { maintaining the safety for others } \\
\text { during the Coronavirus pandemic }\end{array}$} & $\begin{array}{l}\text { Correlation } \\
\text { Coefficient } \\
\end{array}$ & $.501^{* *}$ \\
\hline & Sig. & .000 \\
\hline Tools & $\begin{array}{l}\text { Spearman's } \\
\text { rho }\end{array}$ & $\begin{array}{l}\text { Group discussions through } \\
\text { social media } \\
\end{array}$ \\
\hline \multirow{2}{*}{$\begin{array}{l}\text { they raise awareness on } \\
\text { protection when a family member } \\
\text { gets infected with Coronavirus }\end{array}$} & $\begin{array}{l}\text { Correlation } \\
\text { Coefficient }\end{array}$ & $.613^{* * *}$ \\
\hline & $\begin{array}{l}\text { Sig. } \\
\end{array}$ & $\begin{array}{c}.000 \\
\end{array}$ \\
\hline Roles & $\begin{array}{l}\text { Spearman's } \\
\text { rho }\end{array}$ & $\begin{array}{l}\text { Virtual interviews with the } \\
\text { recovered from the } \\
\text { coronavirus }\end{array}$ \\
\hline \multirow{2}{*}{$\begin{array}{l}\text { they raise awareness on } \\
\text { protection when a family member } \\
\text { gets infected with Coronavirus }\end{array}$} & $\begin{array}{l}\text { Correlation } \\
\text { Coefficient }\end{array}$ & $.553^{* *}$ \\
\hline & Sig. & (2.000 \\
\hline
\end{tabular}




\begin{tabular}{|c|c|c|}
\hline \multicolumn{2}{|c|}{$\begin{array}{l}\text { Egyptian Journal of Social Work (EJSW) } \\
\text { ISSN: 2356-9204 }\end{array}$} & $\begin{array}{r}\text { http://ejsw.journals.ekb.eg } \\
\text { Vol 13, Issue 1, January } 2022 \\
\end{array}$ \\
\hline Roles & $\begin{array}{l}\text { Spearman's } \\
\text { rho }\end{array}$ & $\begin{array}{l}\text { Virtual meetings with } \\
\text { specialists for dealing with the } \\
\text { problems related to the } \\
\text { pandemic }\end{array}$ \\
\hline \multirow{2}{*}{$\begin{array}{l}\text { they increase the knowledge } \\
\text { about the problems related to the } \\
\text { Coronavirus }\end{array}$} & $\begin{array}{l}\text { Correlation } \\
\text { Coefficient }\end{array}$ & $.619^{* *}$ \\
\hline & Sig. & (.000 \\
\hline Roles & $\begin{array}{l}\text { Spearman's } \\
\text { rho }\end{array}$ & $\begin{array}{l}\text { Virtual interviews with the } \\
\text { recovered from the } \\
\text { coronavirus }\end{array}$ \\
\hline \multirow{2}{*}{$\begin{array}{l}\text { they increase the knowledge } \\
\text { about the problems related to } \\
\text { Coronavirus }\end{array}$} & $\begin{array}{l}\text { Correlation } \\
\text { Coefficient }\end{array}$ & $.485^{* *}$ \\
\hline & Sig. & .000 \\
\hline Roles & $\begin{array}{l}\text { Spearman's } \\
\text { rho }\end{array}$ & $\begin{array}{l}\text { Videos raising awareness } \\
\text { about the pandemic }\end{array}$ \\
\hline \multirow{2}{*}{$\begin{array}{l}\text { they emphasize that facing the } \\
\text { pandemic is everyone's } \\
\text { responsibility }\end{array}$} & $\begin{array}{l}\text { Correlation } \\
\text { Coefficient }\end{array}$ & $-.362-^{* *}$ \\
\hline & Sig. & .004 \\
\hline Roles & $\begin{array}{l}\text { Spearman's } \\
\text { rho }\end{array}$ & $\begin{array}{l}\text { Virtual meetings with } \\
\text { specialists for dealing with the } \\
\text { problems related to the } \\
\text { pandemic }\end{array}$ \\
\hline \multirow{2}{*}{$\begin{array}{l}\text { they limit the spread of rumours } \\
\text { related to the Corona pandemic }\end{array}$} & $\begin{array}{l}\text { Correlation } \\
\text { Coefficient }\end{array}$ & $.692^{* *}$ \\
\hline & Sig. & ב.000 \\
\hline Roles & $\begin{array}{l}\text { Spearman's } \\
\text { rho }\end{array}$ & $\begin{array}{l}\text { Videos raising awareness } \\
\text { about the pandemic }\end{array}$ \\
\hline \multirow{2}{*}{$\begin{array}{l}\text { they limit the spread of rumours } \\
\text { related to the Corona pandemic }\end{array}$} & $\begin{array}{l}\text { Correlation } \\
\text { Coefficient } \\
\end{array}$ & $.595^{* *}$ \\
\hline & Sig. & .000 \\
\hline
\end{tabular}

The above-mentioned table shows that there is a statistically significant correlation between the roles and tools of the virtual groups to protect others during the Corona pandemic because there has been a moderate positive correlation between: "they increase awareness on maintaining the safety for others during the Coronavirus pandemic" and "virtual lectures on methods of self-protection during a pandemic" and also, with group discussions through social media". Similarly, there has been a strong positive correlation between: "they raise awareness on protection when a family member gets infected with Coronavirus" and "group discussions through social media". Likewise, there has been a moderate positive correlation between the same role 
and "virtual interviews with the recovered from the Coronavirus". In the same way, there has been a strong positive correlation between: "they increase the knowledge about the problems related to the Coronavirus" and "virtual meetings with specialists for dealing with the problems related to the pandemic". Equivalently, there has been a moderate positive correlation between the same role and "virtual interviews with the recovered from the Coronavirus". While there has been a weak negative correlation between "they emphasize that facing the pandemic is everyone's responsibility" and "videos raising awareness about the pandemic". Also, there has been a strong positive correlation between: "they limit the spread of rumours related to the Corona pandemic" and "virtual meetings with specialists for dealing with the problems related to the pandemic". Likewise, there has been a moderate positive correlation between the same role and "videos raising awareness about the pandemic"

\section{Discussion and practical implications:}

The COVID-19 pandemic is producing an age of social distancing and the virtual environment. Hence, the pandemic has forced groups to move their activities into the virtual space and introduce suitable awareness programs during this special stage. This has been corroborative with one of the studies by McNeely, Schintler, \& Stabile (2020) which has showed that "there is an urgent need for research and policy solutions regarding the impact of the COVID-19".

In addition, this study has shown that the virtual groups roles are not enough to develop self-protection during the pandemic for it is the first experience for the groups to work through the virtual space during the Corona time and its sequential waves.

Moreover, students do not have the appropriate readiness to work on online activities because they do not have enough electronic skills. Therefore, it is necessary to build capabilities and electronic skills for students, as well fostering self-efficacy, and increasingly the students' readiness.

Thus, in this way the virtual groups help to perform many roles to develop self-protection from the Corona pandemic which is consistent with concepts of the role theory such as: "they increase awareness of safety and security procedures against infection with the Coronavirus"; this has been corroborative with one of the articles by Sharma, Vashnav, \& Sharma (2020) which referred to "intensive public awareness programs during the COVID-19 pandemic". 
Likewise, "they provide opportunities to participate in virtual activities and "they emphasize that facing the pandemic is everyone's responsibility" have been confirmed by Usher, Durkin, \& Bhullar's study (2020) which urged "to act in an increasingly unsocial way in order to overcome the challenges of this pandemic and [that] we must remember that we are all in this together and act accordingly".

Additionally, "they emphasize social distancing adherence", "they increase awareness to maintain the safety for others during Coronavirus", "they increase awareness on protection when a family member gets infected with Coronavirus", "they help people learn how to organize time during the Coronavirus pandemic", "they limit the spread of rumours related to the Corona pandemic", "they reduce the fear and panic of infection with Coronavirus"; this has been consistent with one of the articles by Petzold, et al. (2020) which indicated that "the current COVID-19 pandemic does cause psychological distress, anxiety, and depression for large proportions of the general population".

Also, "they increase the knowledge about the problems related to the Coronavirus".

Moreover, the virtual groups used tools to raise awareness of selfprotection during the Corona pandemic such as: "videos raising awareness about the pandemic", "publishing posters in social networking accounts in order to emphasize self-protection during the pandemic", "virtual meetings to organize working in the group", "group discussions through social media about prevention procedures during a pandemic", "virtual lectures about methods of self-protection during a pandemic", "virtual meetings with specialists for dealing with the problems related to the pandemic", "virtual interviews with the recovered from the Coronavirus".

\section{Limitations of the Study:}

-The scarcity of studies and research related to virtual groups during pandemics.

- The inability to interact directly face to face with virtual groups members to determine the realistic role of these groups for providing self-protection during the Corona pandemic.

- The sample in this study did not have enough answers, so the results cannot be generalized for target population. 


\section{Suggestions for Future Research:}

1. Establishing a training program to develop the electronic skills for the members.

2. Disseminating the initiatives related to dealing with the pandemic.

3. Holding workshops to help the youth qualify and deal with crises such as the Corona pandemic.

4. Transferring the scientific expertise from specialists about selfprotection during Corona.

\section{Recommendations:}

- The need to conduct scientific research focused on the foundations and electronic skills of working with virtual groups, the role of electronic networks and applications in the field of groups, and the relationship between virtual groups and awareness of the Coronavirus.

- Relying on the strategy of virtual activities during the coronavirus pandemic (COVID-19).

- Increasing the role of awareness to achieve prevention and selfprotection during pandemics.

- The need to coordinate between virtual groups in the college to create a working system for sustaining the students' activities during pandemics.

\section{Conclusion:}

This study focused on the many obstacles virtual groups face in developing self-protection during the Corona pandemic, especially with the increase in the pace of digital transformation and the existence of digital gaps such as: insufficient activities due to the lack of direct interaction between group members", "students are busy due to the e-learning stresses during the pandemic", "isolation when implementing the program of virtual groups during the pandemic", "the feeling of having marginal relationships with colleagues in the virtual group during the pandemic", "poor coordination during the preparation for virtual group activities", "the lack of collective creativity during the Corona pandemic", "not having sufficient electronic skills that help to interact with the group and achieve its programs and goals".

Hence, we must deal with these obstacles and face them effectively in order to provide an appropriate environment for the virtual groups to do their roles and develop self-protection during the Corona pandemic, such as hygiene, washing hands, avoiding crowded places, social distancing, and virtual encounters. 
Moreover, virtual groups create activities that are more capable of dealing with unexpected challenges.

Finally, the virtual groups roles are not enough to develop selfprotection during the coronavirus pandemic (COVID-19) and need to set heuristic guidelines to help virtual groups find a creative environment during pandemics.

\section{References:}

Bendau, A., Plag, J., Kunas, S., Wyka, S., Ströhle, A., \& Petzold, M. B. (2021). Longitudinal changes in anxiety and psychological distress, and associated risk and protective factors during the first three months of the COVID-19 pandemic in Germany. Brain and Behavior, 11(2). doi:10.1002/brb3.1964

Gopinath, K. S. (2020). Corona - Covid -19 - Pandemic Are we in the Right Direction. Indian Journal of Surgical Oncology, 1(1). doi:10.1007/s13193020-01136-0

Ihm, L., Zhang, H., Vijfeijken, A. v., \& Waugh, M. G. (2021). Impacts of the Covid-19 pandemic on the health of university students. Int J Health Plann Mgmt. doi:10.1002/hpm.3145

Mafugu, T., \& Abel, S. (2020). The pattern of Coronavirus cases in South Africa compared with the United States of America and South Korea. African Journal of Reproductive Health, 24(2), pp. 108-116. doi:10.29063/ajrh2020/v24i2s.15

Majid, U., Wasim, A., Bakshi, S., \& Truong, J. (2020). Knowledge, (mis)conceptions, risk perception, and behavior change during pandemics: A scoping review of 149 studies. Public Understanding of Science, 29(8), pp. 777-799. doi:10.1177/0963662520963365

Marques, I. C., Theiss, L. M., Johnson, C. Y., McLin, E., Ruf, B. A., Vickers, S. M., . . . Chu, D. I. (2020). Implementation of virtual focus groups for qualitative data collection in a global pandemic. The American Journal of Surgery. doi:10.1016/j.amjsurg.2020.10.009

McNeely, C. L., Schintler, L. A., \& Stabile, B. (2020, September). Social Determinants and COVID-19 Disparities: Differential Pandemic Effects and Dynamics. World Medical \& Health Policy, 12(3), pp. 206-217. doi:10.1002/wmh3.370

Petzold, M. B., Bendau, A., Plag, J., Pyrkosch, L., Maricic, L. M., Betzler, F., . . Ströhle, A. (2020, Sep). Risk, resilience, psychological distress, and anxiety at the beginning of the COVID-19 pandemic in Germany. Brain \& Behavior, 10(9), pp. 1-10. doi:10.1002/brb3.1745

Prosser, A. M., Judge, M., Bolderdijk, J. W., Blackwood, L., \& Kurz, T. (2020, July). Distancers and non-distancers? The potential social psychological impact of moralizing COVID-19 mitigating practices on sustained behaviour change. British Journal of Social Psychology, 59(3), pp. 653662. doi:10.1111/bjso. 12399

Scalabrini, A., Xu, J., \& Northoff, G. (2021, Feb). What COVID-19 tells us about the self: The deep intersubjective and cultural layers of our brain. Psychiatry and clinical neurosciences, 75(2), pp. 37-45. doi:10.1111/pcn.13185 


\begin{tabular}{|lr||}
\hline Egyptian Journal of Social Work (EJSW) & http://ejsw.journals.ekb.eg \\
ISSN: 2356-9204 & Vol 13, Issue 1, January 2022 \\
\hline
\end{tabular}

Sharma , I., Vashnav, M., \& Sharma, R. (2020). COVID-19 pandemic hype: Losers and gainers. Indian Journal of Psychiatry, 62, pp. 420-430. doi:10.4103/psychiatry.IndianJPsychiatry_1060_20

Spitzer, M. (2020). Masked education? The benefits and burdens of wearing face masks in schools during the current Corona pandemic. Trends in neuroscience and education. doi:10.1016/j.tine.2020.100138

Usher, K., Durkin, J., \& Bhullar, N. (2020). The COVID-19 pandemic and mental health impacts. International Journal of Mental Health Nursing, 29, pp. 315-318. doi:10.1111/inm.12726 
